\title{
Apontamentos para a compreensão do processo de projeto a partir dos fundamentos da ontologia materialista de G. Lukács
}

\author{
José Rodolfo Pacheco Thiesen*
}

Resumo O artigo pretende abordar elementos teórico-filosóficos, com base na ontologia materialista de György Lukács, a respeito do exercício de projeto em Arquitetura e Urbanismo. Pretende-se tratar o ato conceptivo de projeto como um pôr teleológico mediado pelo mundo objetivo. Este tratamento se diferencia das compreensões que atribuem ao sujeito isolado todas as possíveis qualidades de um bom projetista, com ideias (ou soluções) que surgem de processos estritamente mentais. Ela ajuda a estabelecer uma relação do projetista com seu objeto que é dinâmica e contínua, além de facilitar o trabalho coletivo e se afastar do apelo autoral. Em relação ao ensino, ela visa a não somente formar objetos "bem resolvidos", mas sobretudo sujeitos mais capazes de lidar com os problemas arquitetônicos.

Palavras-chave: ontologia, teleologia, projeto.

\section{Apuntes para la comprensión del proceso de proyecto a partir de los fundamentos de la ontología materialista de G. Lukács House}

\begin{abstract}
Resumen El artículo pretende abordar elementos teórico-filosóficos, con base en la ontología materialista de György Luká$\mathrm{cs}$, respecto al ejercicio de proyecto en Arquitectura y Urbanismo. Se pretende tratar el acto conceptivo de proyecto como un poner teleológico mediado por el mundo objetivo. Este tratamiento se diferencia de las comprensiones que atribuyen al sujeto aislado todas las posibles cualidades de un buen proyectista, con ideas (o soluciones) que surgen de procesos estrictamente mentales. Ella ayuda a establecer una relación del proyectista con su objeto que es dinámica y continua, además de facilitar el trabajo colectivo y alejarse del llamado autoral. En cuanto a la enseñanza, ella pretende no sólo formar objetos "bien resueltos", sino sobre todo sujetos más capaces de lidiar con los problemas arquitectónicos.
\end{abstract}

Palabras clave: ontología, teleología, proyecto.
Notes for the understanding of the design process from the foundations of the materialist ontology of G. Lukács

\begin{abstract}
The article intends to approach theoretical-philosophical elements, based on the materialist ontology of György Lukács, regarding the exercise of project in Architecture and Urbanism. It is intended to treat the conceptional act of design as a teleological goal mediated by the objective world. This treatment differs from the understandings that attribute to the isolated subject all the possible qualities of a good designer, with ideas (or solutions) arising from strictly mental processes. It helps to establish a relation of the designer with his object that is dynamic and continuous, besides facilitating the collective work and moving away from the author's appeal. In relation to teaching, it aims not only to form "well -resolved" objects, but above all, subjects better able to deal with architectural problems.
\end{abstract}

Keywords: ontology, teleology, project. 
0 questionamento das premissas do modernismo em arquitetura abriu um leque imenso de possibilidades formais para o arquiteto contemporâneo. Este leque é tão imenso que nos leva a duvidar da existência de limites para a proposição formal. Grandes nomes da arquitetura contemporânea como Zaha Hadid, Frank Gehry e Peter Eisenman parecem fazer crer que, para o arquiteto, nada mais é impossível. É evidente que os limites existem e que esta ilusão carrega consigo um grande nível de fetichismo'.

As origens exatas desta noção fetichista ou fetichizante são desconhecidas. Se quisermos arriscar uma raiz bastante antiga podemos voltar à afirmação de Alberto o Grande, por volta de 1230, de que "criar é produzir alguma coisa a partir de nada" (apud. JIMENEZ, 1999, p. 33). No auge do pensamento teológico da Idade Média é certo que este poder criador não pertence ao homem e sim somente a Deus. Diante do fato incontestável de que fazer arquitetura é criar, São Tomás de Aquino, discípulo de Alberto, se vê obrigado a fazer uma concessão, afirmando ser o arquiteto "o análogo de Deus" (AQUINO, apud. BRANDÃO, 1999, p. 50).

Mas Deus, sobretudo o Deus da tradição judaico-cristã, é certamente o único ser capaz de criar somente pela vontade, pelo verbo, sem matéria-prima nem condicionantes. "Tu disseste e foram feitos e no teu Verbo os fizeste" (AGOSTINHO, 2008, p. 105). Somente Deus faz milagres, e como bem asseverou Feuerbach: "O milagre é uma creatio ex nihilo, uma criação a partir do nada. Quem transforma água em vinho, este fabrica vinho do nada, porque o elemento do vinho não está na água; caso contrário não seria a produção do vinho milagrosa, mas natural" (FEUERBACH, 2007, p.121).

Já os arquitetos, estes de fato exercem uma função social que os coloca em uma situação bastante especial. Tomás de Aquino não fez em vão seu comentário que compara arquitetos e Deus. Se Deus fez a natureza e o homem produziu para si uma "segunda natureza"2, os arquitetos foram sem dúvida os grandes responsáveis por dar forma a esse mundo humano. A grande diferença reside em que Deus pôde contar com a possibilidade do milagre, enquanto que aos arquitetos restou somente a possibilidade do trabalho.

\section{O projeto como trabalho}

* José Rodolfo Pacheco Thiesen é Arquiteto e Urbanista, Professor na Universidade Federal de Goiás, ORCID <http://orcid.org/00000002-3986-6704>.
O "milagre da arquitetura", como ficou conhecido parte do desenvolvimento da arquitetura moderna no Brasil, não somente recebeu este apelido como realmente dependeu, segundo Lúcio Costa, de um "milagre" (COSTA, 1962). Dentre os arquitetos que se vangloriam por ter realizado o que parecia, a princípio, impossível, destaca-se certamente a figura do "semideus" (palavras de Otávio Leonídio³) Oscar Niemeyer.

Em seu livro Conversa de arquiteto chamam atenção as passagens que se referem ao seu "método de trabalho" projetual. Por exemplo: "Às vezes a idéia surge de repente. Foi o que me aconteceu com a mesquita de Alger, que resolvi durante a 
10 tema é tratado com propriedade por Pedro Fiori Arantes em ARANTES, 2012

${ }^{2} \mathrm{~A}$ expressão tem trajetória própria no campo da filosofia. Lukács se apropria dela em vários momentos de suas mais diversas reflexões.

3LEONÍDIO, 2007.

4 Para evitar injustiças é importante mencionar que Niemeyer prossegue colocando elementos que tornam um pouco mais complexo o processo, sem no entanto, em nossa leitura, alterar a sua essência: "Analiso a ideia surgida e começo a fazer os meus desenhos. As vezes é uma planta, um partido arquitetônico que prevalece, outras vezes é um croquis, uma simples perspectiva que me agrada e procuro testar" . noite, levantando-me de madrugada para desenhá-la" (NIEMEYER, 1993, p. 9). Ou então a seguinte:

Primeiro tomo contato com o problema, o terreno, o programa, o ambiente onde a obra vai ser construída. Depois, deixo a cabeça trabalhar e durante alguns dias guardo comigo no inconsciente o problema em equação, nele me detendo nas horas de folga e até quando durmo ou me ocupo de outras coisas. Um dia, esse período de espera termina. Surge uma idéia de repente e começo a trabalhar. ${ }^{4}$ (NIEMEYER, 1993, pp. 42-3)

Apesar de estar descrito aí um "método de trabalho", tal como sugere o título do capítulo do livro de onde foi extraída essa passagem, uma leitura atenta parece revelar que o trabalho, efetivamente, só se inicia após o surgimento da ideia. Não há trabalho na formação da ideia, a não ser o trabalho mental que parece prescindir do corpo do arquiteto ("deixo a cabeça trabalhar"). O trabalho efetivamente começaria somente no processo de exteriorização ou representação da ideia. A ideia surge após um período de "espera", suas únicas características processuais estão associadas a momentos "de folga", de sono ou de outras ocupações. A ideia, ao que parece, já nasceu pronta ou quase pronta, revelou-se para o arquiteto. Diante desse processo, poderíamos levantar duas hipóteses: ou o arquiteto cumpre apenas uma função de mediador, médium, de algo que vem de outra dimensão, ou o arquiteto é justamente o ponto de origem, de onde partem as ideias sem que nada as preceda (a tal "criação a partir do nada").

Se a ideia é ponto de partida, ponto zero, ela passa a ser inquestionável. Sendo ela antecipação do produto final, do edifício construído, ela é também fim. Ela é, portanto, tal como Deus, ou o Espírito Absoluto de Hegel, "o alfa e o ômega, o princípio e o fim". Tudo o que vem no meio tem que simplesmente se adaptar a ela, servi-la. Eis o fetiche: a ideia, que deveria responder às determinações e necessidades, torna-se ela própria a geradora de demandas. Todo o encadeamento de ações necessárias à materialização do objeto arquitetônico entra em uma espécie de linha de produção, via de mão única: primeiro a ideia, depois o seu detalhamento, depois a execução. Tudo para garantir que o produto final, arquitetônico, possa reproduzir com fidelidade aquela ideia. O projeto seria assim, uma forma de projetar (lançar) no futuro o produto final. Ao final, ideia e produto se encontram, enquanto que o longo processo que os unem parece desaparecer. A nós nos resta a questão: de onde vem a ideia?

\section{O projeto como pôr teleológico}

O projeto de arquitetura tem uma pré-existência, um ponto de origem. Segundo Peter Eisenman

Antes do Renascimento, acreditava-se que a ideia de origem era autoevidente: seu significado e importância dispensavam explicações, faziam parte de um universo apriorístico de valores. Com a perda desse universo de valores autoevidentes durante o Renascimento, as origens passaram a ser procuradas em fontes naturais ou divinas, ou em uma geometria cosmológica ou antropomórfica. A reprodução da imagem do homem vitruviano é o exemplo mais conhecido disso. Não surpreende que, uma vez que se acreditava que a origem contivesse as sementes do propósito do objeto 
${ }^{5}$ A expressão tem longa trajetória na história da filosofia. Os tradutores de Prolegômenos para um ontologia do ser social de Lukács resgataram as linhas gerais dessa trajetória em nota, ver LUKÁCS, 2010, pp. 43-4.

6 Todo o dito na nota anterior vale igualmente para a categoria da causalidade, ver LUKÁCS, 2010, p. 40.

7 Deve-se sobretudo ao filósofo húngaro György Lukács o esclarecimento desta questão. Importante esclarecer: em primeiro lugar, a relação entre teleologia e causalidade de Marx e Engels não se apresentam de maneira "pura" ou "direta" em seus textos, ela foi, digamos, "descoberta" por Lukács, por sua imensa capacidade de interpretação, mas também pelo fato de ele ter tido uma relação ímpar com a obra dos dois alemães (o que envolve, por exemplo, ele ter sido o primeiro a tomar conhecimento dos Manuscritos econômico-filosóficos, texto seminal do pensamento de Marx). Em segundo lugar, essa noção não pode ser atribuída a todo o marxismo, pois ele é constituído de diferentes interpretações da obra de Marx e Engels. Na verdade, Lukács viu no equacionamento dessas duas categorias uma arma para combater interpretações do marxismo que julgava serem demasiado mecanicistas. Nas palavras de Nicolas Tertulian, "A ideia de uma 'necessidade teleológica' do socialismo era nesse sentido refutada explicitamente por Lukács. O socialismo existia para ele somente como possibilidade, e ele exigia que ela fosse recolocada no contexto real do processo histórico" (TERTULIAN, 2011, p. 116). e, portanto, de sua destinação, essa crença na existência de uma origem ideal levou diretamente à crença na existência de um fim ideal. (EISENMAN, 2008, p. 236)

É interessante a observação de Eisenman, embora ele pareça ignorar que a compreensão da existência de um fim ideal que orienta a ação criadora já estava presente em Aristóteles, lá no século $\vee$ a.C. quando este afirmava que "a casa provém da casa que está na mente do artífice" (ARISTÓTELES, 2002, p. 323). Aristóteles faz uma clara alusão à ação teleológica do trabalho do artífice/arquiteto: se a casa provém da casa que está na mente do artífice é porque, antes de construí-la como casa, ele constrói mentalmente uma casa, ou pelo menos uma ideia vaga de como a casa ficaria depois de construída. A casa é, assim, previamente ideada. Eisenman reclama que, após o Renascimento, "a perspectiva do fim governou a estratégia do começo" (EISENMAN, 2008, p. 236). Esquece-se apenas de que esta não foi nenhuma novidade do Renascimento, mas simplesmente a forma como opera o ser social que transforma o seu meio mediante seu trabalho (individual ou coletivo).

A noção de projeto como algo lançado à frente encontra como correspondentes na filosofia o par categorial dialético da "teleologia" e da "causalidade". ténos, ou télos, como se sabe, significa fim. Qualquer coisa que seja teleológica é algo que se caracteriza por sua relação com a finalidade ${ }^{5}$. Já a causalidade se vincula à noção de causa e efeito ${ }^{6}$.

Vimos que esta noção do trabalho como teleologia aparece muito cedo na história da filosofia, já em Aristóteles. Mas ela aparece ainda mais claramente em O capital de Marx, no capítulo V, que trata do "Processo de trabalho" e no qual Marx compara "o pior arquiteto" à "melhor abelha". Marx afirma que "No fim do processo de trabalho obtém-se um resultado que já no início deste existiu na imaginação do trabalhador, e portanto idealmente" (MARX, 1983, pp. 149-150). O trabalhador, assim, inicia o processo de trabalho já com vistas ao seu fim, seu objetivo. "Ele não apenas efetua uma transformação da forma da matéria natural; realiza, ao mesmo tempo, na matéria natural seu objetivo [...] ao qual tem de subordinar sua vontade." (id., p. 150). E mais: "Além do esforço dos órgãos que trabalham, é exigida a vontade orientada a um fim, que se manifesta como atenção durante todo o tempo de trabalho" (id.).

Marx, juntamente com Engels, no entanto, diferente de Aristóteles e de todos os demais filósofos que os precederam, chegam a um equacionamento do par dialético teleologia/causalidade que aqui particularmente nos interessa ${ }^{7}$. Não sendo possível discorrer longamente - tal como seria recomendável - sobre o tema no espaço deste artigo, nos limitaremos a expor o seguinte: para eles as duas categorias só constituem uma unidade (no sentido de uma unidade dialética, portanto, unidade da diversidade) no trabalho (trabalho humano, considerando o ser humano como o único animal que trabalha), isto porque o trabalho é a primeira manifestação da teleologia:

Marx nega a existência de qualquer teleologia fora do trabalho (da práxis humana) [...], para Marx, o trabalho não é uma das muitas formas fenomênicas da teleologia em geral, mas o único ponto onde se pode demonstrar ontologicamente um pôr teleológico como momento real da realidade material. (LUKÁCS, 2013, p. 51) 
Estabelece-se assim, para Marx e Engels, uma compreensão de que o trabalho se constitui como a categoria fundante do ser social (ser humano). Ele é o "modelo de toda práxis social" (LUKÁCS, 2013, p. 47). Lukács percebe que, para Marx, o surgimento da teleologia, o surgimento do trabalho e o surgimento do ser social são partes constituintes de um mesmo "salto ontológico". Isto lhe permite compreender o ser em três grandes esferas coexistentes:

1) O ser inorgânico: pense-se aqui na formação do planeta Terra, por exemplo, com múltiplas interações e desencadeamentos de processos físico-químicos, mas ainda sem vida orgânica;

2) O ser orgânico: resultado de um salto ontológico no qual surgem os organismos vivos, sendo que a vida não deixa de ser fruto de um determinado arranjo de processos físico-químicos que passam então a se dar como processos também biológicos. Nesta esfera se inicia o processo de adaptação ao meio (analisado pela teoria da evolução de Darwin), mas ainda como uma "adaptação passiva" e, portanto, dentro do espectro da causalidade apenas;

3) O ser social: um ser orgânico, composto por elementos químicos, físicos e biológicos, mas que dá um salto mediante o trabalho com sua dimensão teleológica e todos os desdobramentos que daí decorrem historicamente - incluindo a linguagem, a consciência e a noção da própria genericidade do ser humano - passando a se organizar como uma nova esfera do ser, na qual se inclui apenas o gênero humano. Nesta esfera o ser ganha um desenvolvimento também social e a "adaptação passiva" ao meio se transforma em "adaptação ativa", que conta com a atividade orientada a um fim do sujeito consciente.

\section{A relação sujeito-objeto}

Uma vez que somente na esfera do ser social é possível uma teleologia, o que opera nas demais esferas é, portanto, somente a relação causal. Uma vez que a teleologia é "inaugurada", pois que surge, com o trabalho, inaugura-se também neste mesmo processo a relação sujeito-objeto. As cadeias causais nada mais são que relações entre objetos. Somente com o surgimento de um ser capaz de operar teleologicamente, pondo finalidade em cadeias causais, é que podem surgir sujeitos em relação ao mundo objetivo ${ }^{8}$.

Ao agir teleologicamente, o trabalhador materializa, fora de si, o seu objetivo inicial, em um objeto. Parafraseando Marx: no produto do trabalho, o trabalho se une com seu objetivo, o trabalho é objetivado e o objeto é trabalhado (MARX, 1983, p. 151). Somente na ação teleológica é que há movimento partindo do sujeito em direção ao objeto. Mas, independente disso, é o objeto que preexiste com relação ao sujeito, e não o contrário. Além do mais, o papel do sujeito, o trabalhador, no processo de trabalho como ação teleológica é somente o de, nas palavras de Engels, "provocar um movimento particular" ao estabelecer "as condições em que, na natureza, os mesmos se verificam" (ENGELS, 1979, p. 138).

Para a existência de um tijolo, o moleiro prepara a argila - isentando-a de grumos e bolhas - e o carpinteiro que fabrica o molde - materializando a forma no fazer 
o molde - trabalham no encadeamento de meios técnicos e preparam a operação técnica. O trabalhador que entrega a matéria ao molde, comprime-a, promovendo o encontro entre forma e matéria, prepara a mediação: mas é a argila que toma forma segundo o molde, não o indivíduo que promove a operação. (LOPES, 2006, p. 212)

A diferença é que, mediante a ação teleológica do trabalho, o surgimento de algo novo é possibilitado por um arranjo causal que só é experimentado pela iniciativa do sujeito:

Algo inteiramente novo surge dos objetos, das forças da natureza, sem que haja nenhuma transformação interna; o homem que trabalha pode inserir as propriedades da natureza, as leis do seu movimento, em combinações completamente novas e atribuir-Ihes funções e modos de operar completamente novos. Considerando, porém, que isso só pode acontecer no interior do caráter ontológico insuprimível das leis da natureza, a única mudança das categorias naturais só pode consistir no fato de que estas - em sentido ontológico - tornam-se postas; esse seu caráter de terem sido postas é a mediação da sua subordinação ao pôr teleológico determinante, mediante o qual, ao mesmo tempo que se realiza um entrelaçamento posto de causalidade e teleologia, tem-se um objeto, um processo etc. unitariamente homogêneo. (LUKÁCS, 2013, p. 55)

Tudo isso nos interessa porque demonstra que o poder de criação do trabalho encontra no mundo objetivo um universo imenso de possibilidades, mas encontra também limites, já que a criação só é viável atendendo às leis da natureza e (re) organizando elementos do mundo objetivo que são pré-existentes. Lukács se refere a este conflito como um conflito entre determinidade e liberdade, em oposição às diversas correntes filosóficas que a situam como estando entre a necessidade e a liberdade (LUKÁCS, 2013, p. 142). A ilusão de que a liberdade da criação humana se coloca acima desses limites da determinidade, ou de que ela responde apenas à necessidade, é um elemento importante para a constituição do processo de fetichização da arquitetura.

\section{Meios e fins}

9 Lukács e Simmel relacionaramse em vida. Por volta de 1910 Lukács foi aluno de Simmel em Berlim, e foi muito influenciado por ele. Com a eclosão da Primeira Guerra Mundial em 1914 e sobretudo após a morte de Simmel em 1918 Lukács inicia um processo de distanciamento daquelas influências, até a sua contraposição. Neste período Lukács consolida sua fundamentação marxista. Simmel dialogava com o pensamento de Marx, mas seus fundamentos filosóficos eram, segundo Nicolas Tertulian (2008), principalmente kantianos, a ponto de ele buscar construir uma interpretação kantiana para problemas levantados por Marx (por exemplo, o próprio fetichismo da mercadoria).
É conhecido no meio marxista a reflexão a respeito do fetichismo da mercadoria. No tópico que encerra o primeiro capítulo e O Capital, Marx faz a instigante afirmação de que, no modo de produção capitalista as relações entre pessoas se reificam e as relações entre coisas se tornam relações sociais (MARX, 1983, p. 71). Marx teve muito cuidado ao restringir essa inversão ao modo de produção capitalista, mostrando que ela nem sempre ocorreu e, principalmente, pode ser superada no futuro.

Este cuidado em não generalizar a reificação das relações sociais e o fetichismo da mercadoria a todas as formas de sociedade (modos de produção) não foi tomado por pensadores posteriores a Marx que teoricamente o tinham como referência. Um deles é Simmel ${ }^{9}$, de quem nos apropriaremos transitoriamente para auxiliar, como termo de comparação, no desenvolvimento de algumas reflexões. Simmel afirma, em seus "Fragmentos e ensaios", que "O 'caráter fetichista' que Marx atribui aos objetos econômicos na época da produção de mercadorias não é senão uma variante específica deste destino geral de nossos conteúdos culturais" (SIMMEL apud. LUKÁCS, 1959, p. 367). 
10 Interessante observar a posição de Lukács a este respeito: ver LUKÁCS, 2013, p. 52.
E não é somente da transitoriedade dessa relação que Simmel se descuida. Para ele teleologia e causalidade também não formam um par específico e exclusivo da relação do ser social com o ser natural (orgânico e inorgânico). Em Simmel a teleologia é privilegiada com relação à causalidade ${ }^{10}$. Buscando esclarecer de modo muito sucinto essa diferença, podemos utilizar como exemplo o fato de que Simmel admite a existência de Deus afirmando que este não teria nem fim nem meios, uma vez que ao criar ele o faz imediatamente (voltamos aqui, portanto, à ideia de criação a partir do nada). Não há, portanto, uma compreensão da causalidade que permita a Simmel compreender o mundo objetivo como independente da consciência cognoscente.

Mais que isso, as reflexões de Simmel a respeito da relação entre teleologia e causalidade têm como centralidade a inversão entre meios e fins na vida do indivíduo moderno. A vida do sujeito da modernidade estaria, segundo Simmel, marcada por um excesso de mediações: para o homem primitivo a relação entre fim (teleologia) e meios (que para ele são as causalidades) estava muito próxima, mas na medida em que a sociedade vai se complexificando, vão sendo inseridas mais e mais mediações neste processo, acarretando o que Simmel chama de um prolongamento das "cadeias teleológicas". Neste processo, pela necessidade de um fim e na ausência de uma Bildung (formação cultural) suficiente para reconhecer esse complexo de mediações, o homem moderno acaba por tomar meios como se fossem fins. Esta seria, ainda segundo Simmel, a tragédia da cultura. Coloca-se aqui, portanto, um aparente beco sem saída.

\section{Causalidade e cotidianidade}

Uma grande contribuição de Lukács é a de ter produzido uma reflexão aprofundada a respeito da categoria da cotidianidade. Segundo ele, a vida cotidiana do ser social vai se enriquecendo ao longo do desenvolvimento histórico e social (aqui há concordância com Simmel), mas, por mais que haja nela aplicação de conhecimento científico complexo, ela volta a apresentar-se ao homem como cotidianidade. Lukács ilustra essa questão com um exemplo simples: "Cozinhar ou assar carne é uma mediação, mas comer a carne cozida ou assada é, nesse sentido, um fato tão imediato como o de comer a carne crua, ainda que este última seja natural e o primeiro, social" (LUKÁCS, 2013, p. 128).

A estrutura do MASP (um produto social) ou a estrutura da Rainbown Bridge National Monument, uma formação rochosa no sul do estado de Utá, nos EUA (um produto natural), são complexas e difíceis de explicar. Ambas estão em pé por uma série de arranjos causais, com a diferente de que em um dos casos essa causalidade foi "posta" e, no outro, não.

Para Lukács o mundo objetivo sempre foi complexo, e o problema para o homem contemporâneo - diferente do que pensava Simmel - não é o excesso de causalidades (que para Simmel era o mesmo que excesso de mediações) criado pelo desenvolvimento da sociedade. O mundo objetivo é e sempre foi repleto de relações causais, tenham elas sido postas ou não. O desafio é tomar consciência destas relações tais como elas operam objetivamente. Para isso, ainda segundo Lukács, é necessário se elevar acima da cotidianidade. O pensamento cotidiano é aquele que não se descola da imediatidade, e o descolamento da imediatidade é o que se desenvolve nas formas que se diferenciam do pensamento cotidiano, como a ciência e a arte. 
Se por um lado, "uma consideração ontológica do ser social é impossível sem procurarmos seu primeiro ponto de partida nos fatos mais simples da vida cotidiana dos homens" (LUKÁCS, 2010, p. 37), por outro, "na vida cotidiana o verdadeiro ser muitas vezes se revela de maneira altamente distorcida" (id. ibid.). Em grande parte, essa distorção ocorre por conta justamente do ato de que o olhar do ser social é um olhar ativo, assunto que trataremos adiante. Por ora:

os modos de manifestação imediata encobrem o essencial do ser efetivo, em parte nós mesmos projetamos no ser, com silogismos analógicos precipitados, determinações que são totalmente estranhas a ele, apenas imaginadas por nós. (LUKÁCS, id. ibid.)

A afirmação de Simmel de que o desenvolvimento da sociedade cria uma quantidade imensa de mediações e isso afasta o sujeito de uma compreensão de sua inserção no mundo é vista por Lukács de modo completamente diferente e até oposto. Para este último as mediações necessárias para se construir algo muito complexo ficam incorporadas ao objeto e só se revelam se um sujeito for em busca delas. Neste sentido, dialeticamente, teoria também é prática.

\section{Abstrato e concreto}

O MASP é, em si e em sentido filosófico, um objeto concreto. O concreto, segundo Marx, "é concreto porque é a síntese de múltiplas determinações, portanto, unidade da diversidade" (MARX, 2011, p. 54). Essa unidade precisa ser rompida pela pesquisa para poder ser analisada: é necessário romper com a totalidade contraditória para poder analisar os diferentes polos da contradição. Com isso, chega-se à análise das categorias abstratas. Mas em seguida é necessário retornar ao todo contraditório, montar novamente o todo despedaçado, para construir o "concreto pensado", ou seja, para refigurar mentalmente aquela totalidade concreta em pensamento.

Este rompimento da pesquisa é algo extremamente habitual na vida, por exemplo, de um calculista estrutural: é necessário sempre calcular cada peça estrutural separadamente, mesmo sabendo que elas formam um todo e que esse todo não é uma mera soma das partes. A ação de conjunto de uma estrutura modifica o funcionamento das partes. Por outro lado, se não for conhecido o funcionamento de cada parte, de nada adiantará saber que a ação de conjunto a modifica, pois não será possível saber "como" nem o "quanto" ela é modificada.

Ao se calcular uma viga em detrimento de sua inserção no conjunto da estrutura estamos procedendo com uma abstração. Abstraímos o todo para analisar a parte. Mas se, ao contrário, quisermos analisar o conjunto sem conhecer as partes, também estaremos procedendo com uma abstração. Neste caso abstraímos as partes e olhamos só para o conjunto como uma generalidade abstrata. É somente depois de conhecer a totalidade concreta, que inclui a generalidade e também cada parte no interior dela, seus nexos e relações, que chegaremos a conhecer concretamente o objeto.

Não se deve confundir abstração ou concreção com universalidade ou singularidade, com a generalidade ou a sua decomposição. Tanto o universal quanto o singular, tanto o conjunto quanto a parte, podem ser concretamente compreendidos, desde que compreendidos em sua totalidade, ou o que possa ser o mais próximo dela. 
O paulistano comum que ignora o jogo de forças que mantém em pé a estrutura do MASP não está exatamente abstraindo elementos daquela estrutura, ele simplesmente as ignora. Mas um estudante de arquitetura deve se tornar cada vez mais capaz de realizar e desfazer abstrações a respeito de estruturas que lhe interessam.

O mesmo vale para o processo projetual, embora este seja mais complexo por ser antecipação a algo ainda inexistente. De qualquer maneira, seria impossível conceber um projeto como um todo que já aparece pronto no pensamento. O processo de projeto deve necessariamente envolver diversos momentos de abstração e concretização. É impossível, para dar um exemplo extremo mas ilustrativo, pensar nos detalhes das instalações elétricas quando se está elaborando a volumetria. O projetista sabe que em algum momento chegará nestes detalhes, mas se não fizer um exercício de abstração não conseguirá propor volumetria nenhuma.

Ao desenhar uma planta baixa, por exemplo, o projetista já está lidando com uma figura bastante abstrata (em relação ao projeto em formação), pois ali não estão representados vários elementos daquele projeto (a cobertura, por exemplo). Ao produzir uma maquete ele já passa a trabalhar com um objeto bem mais concreto (mais sintetizador de múltiplas determinações), embora ainda extremamente abstrato por se constituir de materiais totalmente diferentes daqueles com os quais se almejaria construir efetivamente o produto arquitetônico real.

Independente disso, a todo momento o projetista terá que realizar operações mentais antecipatórias tanto de concretização - como imaginar aquela edificação em funcionamento, seus fluxos, etc. - como de abstração - como imaginar apenas o funcionamento estrutural da edificação por detrás dos outros elementos representados, por exemplo.

A bem da verdade, o simples ato de projetar fora do canteiro de obras, aquilo que Sérgio Ferro chamou de "desenho separado" (FERRO, 2010, p. 14), é por si só um grande ato de abstração, uma verdadeira máquina de abstrair. Ao representar com duas linhas paralelas uma parede de tijolos, argamassa e revestimento, abstrai-se todo o árduo trabalho de fabricação de tijolos, produção de cimento, extração de areia, preparação da massa no traço correto, assentamento de tijolo por tijolo atendendo às exigências de prumo e nível, etc.

A capacidade de abstrair é, portanto, uma ferramenta fundamental para o projetista, sem a qual ele não conseguiria projetar. Por outro lado, se um projetista almeja alcançar um alto nível de liberdade no exercício de sua criação, esta capacidade de abstrair não deve jamais prescindir da necessidade de conhecer concretamente a realidade na qual ele pretende intervir.

Quanto maior for o conhecimento das cadeias causais que operam em cada caso, tanto mais adequadamente elas poderão ser transformadas em cadeias causais postas, tanto maior será o domínio que o sujeito exerce sobre elas, ou seja, a liberdade que aqui ele pode alcançar. (LUKÁCS, 2013, p. 140)

A crença de que projetos mais "livres" são aqueles menos constrangidos por determinações é altamente ilusória. Estes projetos podem até ser livres em seu "traço", é uma liberdade "de papel". Essa "liberdade de papel" tropeçará logo em seguida 
na dificuldade de se obter meios técnicos necessários para a transformação daquele traço em um objeto arquitetônico efetivo. Sua execução só será possível contando com a ausência de liberdade do trabalhador da construção civil.

\section{Pergunta e resposta}

Entendemos que algumas boas sínteses a respeito de como se dá o processo de projeto podem ser encontradas, por exemplo, nos esforços do neorracionalismo italiano de Vittorio Gregotti.

São documentos da formação da imagem não só os esboços com que fixamos alguns aspectos provisórios, mas também as anotações, os gráficos, os documentos com os quais indagamos e escolhemos os dados do problema e os pomos em discussão. Nosso percurso através deles nunca é retilíneo, mas uma paciente e contínua reelaboração, uma tentativa de solidificação do projeto em torno de alguns núcleos prontos a liquefazerem-se à simples introdução de um dado imprevisto ou diversamente interpretável, ao abrir-se uma possibilidade construtiva, ao defrontar-se com uma incongruência. Através deste trabalho paciente, longo, fatigante, manual (e quem não se situe neste ponto de vista de trabalho operário não poderá jamais ser arquiteto), o tema é explorado; este nosso conhecimento, a princípio geral e esquemático, é logo retomado, à procura de imagem, em todas as direções; pode estar centrado em qualquer ponto do projeto, numa secção, num detalhe; capacita-nos cada vez mais para a reelaboração total do tema e, ao mesmo tempo que se vai tornando preciso o conhecimento, vai-se precisando a figura. Deste ponto de vista, o meio de representação não é nunca indiferente ou objetivo, aliás, nem chega a ser meio: indica e forma parte da intenção projetual. Isso porque, de um lado, não se trata da representação de uma coisa dada (o artista - diz Merleau-Ponty - possui uma só meio para representar a obra na qual trabalha: deve realizá-la), mas sim da conversação projetual que nós travamos não só com a matéria arquitetônica mas também com a própria representação como matéria que nos responde e sugere e que, por sua vez, é invenção funcional em relação ao objeto ou ao conjunto. É relativamente casual o fato de esta conversação realizar-se através do desenho: mas o exercício do desenho, do instrumento de representação da coisa é a única relação corpórea remanescente que o arquiteto efetua com a fisicidade da matéria que deve formar: é sua última "manualidade" e ele deve defendê-la obstinadamente. (GREGOTTI, 1975, pp. 23-25)

O que se evidencia aí é que o processo de projeto envolve necessariamente aquilo que Gregotti sabiamente chama de "conversação projetual com a matéria arquitetônica".

Lukács demonstra muito claramente como a possibilidade dessa "conversação", ou seja, desse jogo de perguntas e respostas entre sujeito (projetista) e objeto (projeto), só é possibilitada pela práxis social, ou seja, pelo trabalho, e é portanto uma exclusividade humana. Segundo ele todo ser vivo, incluindo aí o ser social, responde ao seu meio, mas somente por meio da práxis humana é que "a influência do meio ambiente adquire o caráter de pergunta" (LUKÁCS, 2013, p. 303).

A possibilidade ilimitada de desenvolvimento desse jogo dialético de pergunta e resposta funda-se no fato de que a atividade dos homens não só contém respostas ao entorno natural, mas também que ela, por sua vez, ao criar coisas novas, necessaria- 
11 Ver LUKÁCS, 2013, p. 65. mente levanta novas perguntas que não se originam mais diretamente do entorno imediato, da natureza, mas constituem tijolos na construção de um entorno criado pelo próprio homem, o ser social. (id. ibid.)

Este diálogo precisa, portanto, ser percebido e interpretado pelo projetista. A percepção passa centralmente e necessariamente, lembrando da ênfase dada por Gregotti à palavra "imagem", pelo olhar. E já que estamos tratando de ensino, temos que encarar a seguinte questão: é possível aprender a ver?

\section{O olhar}

Marx, com sues Manuscritos Econômico-Filosóficos, deu início a uma série de reflexões a respeito do papel dos cinco sentidos na formação do ser social. Segundo ele "A formação dos cinco sentidos é um trabalho de toda a história do mundo até aqui" (MARX, 2004, p. 110). Lukács desenvolve, a partir desta base, uma série de reflexões que o conduzem à conclusão de que os sentidos humanos não cumprem uma função meramente reativa como ocorre com os animais ${ }^{11}$, mas também uma função ativa, pois são atividade de um sujeito.

Em uma aula expositiva, por exemplo, com alunos comodamente sentados em suas cadeiras, apoiando seus cotovelos sobre a carteira, imóveis, o professor costuma exigir algo: atenção. Ao prestar atenção o aluno deixa de ser um objeto para tornar-se sujeito de uma ação, pois os sons emitidos deixam de ser apenas ruídos que fazem vibrar seus tímpanos e passam a ser interpretados pelo cérebro como linguagem, conceitos, estabelecendo relações com sua memória, etc. Trata-se aí, em última instância, de uma atividade e não de uma passividade (embora seja uma atividade bastante limitada, por ser quase que exclusivamente mental), e mais, de uma atividade que só o ser social é capaz de executar.

O saber ver o projeto é semelhante: o projetista não se coloca diante do projeto com os olhos abertos esperando passivamente que a imagem entre em seu cérebro. Pelo contrário, ele precisa ver ativamente e segundo uma intenção, teleologicamente. Ele precisa procurar algo que pode ser uma ou algumas determinações em específico, em meio a um objeto que é, em si, "síntese de múltiplas determinações" (MARX, 2011, p. 54). Ao ver ele já se orienta por uma finalidade. Nos parece que é precisamente aqui que o processo de ensino-aprendizagem deve atuar: construindo no sujeito habilidades relacionadas a este procurar, no sentido de desenvolver capacidades de enxergar com cada vez maior criticidade.

É necessário lembrar, no entanto, que o projeto de arquitetura é projeto de algo que ainda não existe no mundo objetivo, é uma antecipação ao real. Daí que a objetivação seja tão fundamental: algo que não existe de maneira nenhuma na realidade jamais poderá ser analisado. Por isso a ideia precisa ser objetivada ainda que na forma de representações abstratas (plantas, maquetes), desde que estas representações sejam objetivas. Tais representações são responsáveis por criar um esboço de realidade, esta sim passível de análise.

Somente sendo objetivado é que um projeto pode passar a ser criticado. Por isso, em uma aula de projeto, a máxima de que "o papel aceita tudo" deve ser substituída por 
$12 \mathrm{O}$ verso de Alberto Caeiro, personagem de Fernando Pessoa, se tornou também título do excelente artigo de Leyla PerroneMoisés (1997) "a ideia aceita tudo". Uma vez que a ideia é colocada no papel ela ganha objetividade e esta objetividade é fundamental para estabelecer claramente uma comunicação, seja entre aluno e professor, seja do projetista com ele mesmo ou com seus parceiros de projeto. É preciso fazer para ver, e ver para resolver (refazendo, tantas vezes quantas forem possíveis ou necessárias). Pensar não basta, pois sem objetividade a ideia tende a ignorar problemas fundamentais. Alberto Caeiro já versava: "pensar é estar doente dos olhos"12.

\section{Ponto de partida e ponto de chegada}

Segundo Sérgio Ferro "arquitetura é práxis, comunhão de teoria e prática, ação racional crítica" (FERRO, 2008, p. 20). Complementa ainda dizendo que "A ação racional crítica da arquitetura não visa à simples reprodução do presente - mas sua transformação" (id. ibid.). Ao discutir a relação entre pesquisa e experimentação, Ferro chega à conclusão de que a experimentação em arquitetura tem um sentido muito preciso: somente ela pode promover a "pesquisa autêntica" (id. ibid.). E mais: defende que a pesquisa, como experimentação, deve se constituir como o "polo determinante" das escolas de arquitetura (id. p. 19).

Quando tratamos do ensino de arquitetura, em especial o ensino de projeto, existe um absoluto consenso de que não é possível efetivá-lo se o aluno for passivo no processo de ensino-aprendizagem. Para aprender a projetar só há um jeito: é necessário projetar, ter a experiência de enfrentar as situações problema e dar resposta a elas. Não há como, portanto, aplicar aquilo que Paulo Freire criticou como sendo a "educação bancária", que pressupõe alunos que não sabem absolutamente nada. É necessário partir do pressuposto de que os alunos são capazes de projetar e dar a eles a oportunidade de tentar, de modo a ir contribuindo ao longo do processo para que suas habilidades se desenvolvam. Aprender a projetar envolve, portanto, um processo de experimentação.

Neste sentido, compreendendo haver consonância com a linha de raciocínio desenvolvida até aqui, recorremos ao teórico da educação Dermeval Saviani para refletir a respeito desse processo:

o movimento que vai da síncrese ("a visão caótica do todo") à síntese ("uma rica totalidade de determinações e de relações numerosas") pela mediação da análise ("as abstrações e determinações mais simples") constitui uma orientação segura tanto para o processo de descoberta de novos conhecimentos (o método científico) como para o processo de transmissão-assimilação de conhecimentos (o método de ensino). (SAVIANI, 2008, p. 59)

No caso do ensino de arquitetura, as disciplinas de projeto deveriam ser o momento de síntese não somente das experiências oriundas da prática social dos estudantes fora da universidade, mas também dos conteúdos trabalhados nas demais disciplinas. Mas como operar essa síntese quando a "conversação com a matéria arquitetônica" à qual se refere Gregotti é sempre experimentada apenas abstratamente (com materiais que representam os reais apenas do ponto de vista formal)? Quando Gregotti afirma (na citação anterior) que a relação manual do projetista com o desenho é a "única relação corpórea remanescente que o arquiteto efetua com a fisicidade da matéria que deve formar" ele está alertando para a possibilidade da perda de todas as relações 
corpóreas. Infelizmente essa possibilidade é real, e sua efetivação poderia transformar a arquitetura, especialmente o canteiro de obras, em um lugar ainda mais violento e submisso aos caprichos do idealizador individual.

Fazer arquitetura é, necessariamente, movimentar o corpo no espaço. Mover a matéria natural, rearranjá-la no espaço a fim de produzir um espaço habitável. Sem corpo em movimento não existe a possibilidade da estática da arquitetura. No sentido contrário, projetar tem se tornado uma atividade que envolve cada vez menos movimentos, muitas vezes apenas o movimento de apenas um dedo sobre o mouse. Esta retirada do corpo no processo de produção da arquitetura a torna cada vez menos humana, ou menos antropomorfizadora, para usar um conceito lukacsiano (ver sua Estética). A abstração que, no trecho citado da obra de Saviani, deveria ser a mediação do processo que leva da síncrese à síntese, tomou conta também do ponto de partida e do ponto de chegada do processo de ensino-aprendizagem em arquitetura (e urbanismo). Ela vai se tornando a abstração da própria presença do corpo humano na arquitetura.

É muito importante que o ensino de arquitetura priorize a experimentação, especialmente a experimentação em canteiro (experimental). E além disso, que priorize a produção manual de produtos tridimensionais arquitetônicos, ainda que sejam maquetes. Segundo Marx "A produção [...] produz não somente um objeto para o sujeito, mas também um sujeito para o objeto" (MARX, 2011, p. 44). O arquiteto urbanista formado deve ter habilidades que lhe permitam projetar produtos arquitetônicos de qualidade. A qualidade, portanto, tem que estar no produto, no objeto. Já o arquiteto urbanista em formação pode prescindir da qualidade do produto, pois suas habilidades ainda estão sendo construídas. O que precisa aparecer ao final do processo de formação não são bons produtos, mas uma boa produção. Não mais um objeto, mas um sujeito bem formado.

\section{Considerações}

A concepção projetual em arquitetura é uma expressão bastante complexa do que Lukács denominou como o pôr teleológico do trabalho. Não foi por acaso que a arquitetura se tornou exemplo de ação teleológica de diversos grandes filósofos, passando por Aristóteles e Marx.

A ideia do grande arquiteto individual, o autor único de grandes projetos, é na verdade uma falácia. Mas esta falácia ganha cada vez mais força, dado o sistema midiático que envolve o mainstream da arquitetura contemporânea. Muitos trabalham, mas somente um ou, no máximo, dois (em geral homens brancos), aparecem como autores. Isto responde a um processo histórico de concentração e monopolização de atribuições nas mãos dos arquitetos, processo que foi muito bem elucidado pelas pesquisas de Sérgio Ferro.

A unidade compositiva da arquitetura, que até o fim da Idade Média era apenas o resultado da unidade do processo produtivo, se transformou numa unidade imposta

13 A constatação dessa transformação de fundo na arquitetura é de Sérgio Ferro. Ver, por exemplo, FERRO, 2010. e artificial, operada a partir do produto final idealizado ${ }^{13}$. O produto final idealizado aparece agora não mais como uma idealização coletiva, o que de fato é, mas como obra individual e autoral. Todas as contribuições que, ao longo do processo (que envolve detalhamento de projeto, execução, etc.) e que retroagem sobre a concepção inicial 
do arquiteto aparecem como sendo partes desta concepção, como se os projetos pudessem nascer prontos. Este tipo de ilusão atrapalha em muito a formação de novos arquitetos dentro das escolas de arquitetura, pois é necessário todo um árduo trabalho pedagógico para demonstrar que projetar é trabalhar, e muito, pois nenhuma ideia genial vai surgir pronta para ser executada.

\section{Referências bibliográficas}

AGOSTINHO, S. Confissões. Livros VII, X e XI. Covilhã: LusoSofia Press, 2008.

ARANTES, P. F. Arquitetura na era digital-financeira: desenho, canteiro e renda da forma. São Paulo: Editora 34, 2012.

ARISTÓTELES. Metafísica. Edição de G. Reale. São Paulo: Loyola, 2002.

BRANDÃO, C. A. L. A formação do homem moderno vista através da arquitetura. 2. ed. Belo Horizonte: UFMG, 1999.

COSTA, L. Muita construção, alguma arquitetura e um milagre. Revista-Catálogo do III Congresso Interamericano da Indústria da Construção. Rio de Janeiro, 1962.

ENGELS, F. A Dialética da Natureza. 4.ed. Rio de Janeiro: Paz e Terra, 1979.

EISENMAN, Peter. O fim do clássico: o fim do começo, o fim do fim. In: NESBITT, Kate (org.). Uma nova agenda para a arquitetura - antologia teórica (1965-1995). 2 ed. Cosac Naify, 2008.

FERRO, S. Arquitetura e trabalho livre. São Paulo: Cosac Naify, 2006.

A história da arquitetura vista do canteiro: três aulas de Sérgio Ferro. São Paulo: GFAU, 2010.

Experimentação em arquitetura: práxis crítica e reação conservadora. In: RONCONI, Reginaldo (apres.) Canteiro Experimental: 10 ano na FAU USP. São Paulo: FAUUSP, 2008.FEUERBACH, L. A essência do cristianismo. Petrópolis: Vozes, 2007.

GREGOTTI, V. Território da arquitetura. São Paulo: Perspectiva/Edusp, 1975.

JIMENEZ, Marc. O que é estética?. São Leopoldo: Ed. UNISINOS, 1999.

LEONÍDIO, O. Milagre de concreto. Folha de São Paulo. 09 de dezembro de 2007. Disponível em: <http://www1.folha.uol.com.br/fsp/mais/fs0912200710.htm>. Acesso em: 13 abr. 2017.

LOPES, J. M. de A. Em memória das mãos: o desencantamento da técnica na arquitetura e no urbanismo. 2006. Tese (Doutorado) - Programa de pós-graduação em filosofia e metodologia das ciências, Centro de educação e ciências humanas, Universidade Federal de São Carlos, São Carlos, 2006.

LUKÁCS, Georg. El asalto a la razón. México/Buenos Aires: Fondo de Cultura Económica, 1959.

Estética l: La peculiaridad de lo estético. Vol. 1: Cuestiones preliminares y de principio. 3 ed. Barcelona; Buenos Aires; México D.F.: Ediciones Grijalbo, 1974.

Estética I: La peculiaridad de lo estético. Vol. 2: Problemas de la mímesis. 2 ed. Barcelona; Buenos Aires; México D.F.: Ediciones Grijalbo, 1972.

Introdução a uma estética marxista: Sobre a categoria da particularidade. Rio de Janeiro: Civilização Brasileira, 1978. 
LUKÁCS, Georg. O jovem Marx e outros escritos de filosofia. 2 ed. Rio de Janeiro: Editora da UFRJ, 2009.

Para um ontologia do ser social II. São Paulo: Boitempo, 2013.

Prolegômenos para uma ontologia do ser social: questões de princípio para um ontologia hoje tornada possível. São Paulo: Boitempo, 2010.

MARX, Karl. Grundrisse: manuscritos econômicos de 1857-1858: esboços da crítica da economia política. São Paulo: Boitempo, 2011.

O Capital: crítica da economia política. O processo de produção de capital Volume I. Tomo I. São Paulo: Abril Cultural, 1983.

Manuscritos econômico-filosóficos. São Paulo: Boitempo, 2004.

NIEMEYER, O. Conversa de arquiteto. Rio de Janeiro: Revan, 1993.

PERRONE-MOISÉS, L. Pensar é estar doente dos olhos. In: NOVAES, A. et al. O olhar. São Paulo: Companhia das Letras, 1997.

SARAMAGO, R. C. P. Ensino de estruturas nas escolas de Arquitetura do Brasil. 2011. Dissertação (Mestrado) - Escola de Engenharia de São Carlos, Universidade de São Paulo, São Carlos, 2011

SAVIANI, Dermeval. Escola e democracia. Edição comemorativa. Campinas: Autores Associados, 2008.

TERTULIAN, N. Hartmann e Lukács: uma aliança fecunda (Parte II). Crítica Marxista, n. 33, 2011. 2008

Georg Lukács: Etapas de seu pensamento estético. São Paulo: Editora UNESP,

WHITAKER, J. S. Perspectivas e desafios para o jovem arquiteto no Brasil: qual o papel da profissão? Arquitextos, São Paulo, ano 12, n. 133.07, Vitruvius, jul. 2011. Disponível em: <http://www.vitruvius.com.br/revistas/read/arquitextos/12.133/3950>. Acesso em: 10 abr. 2017. 